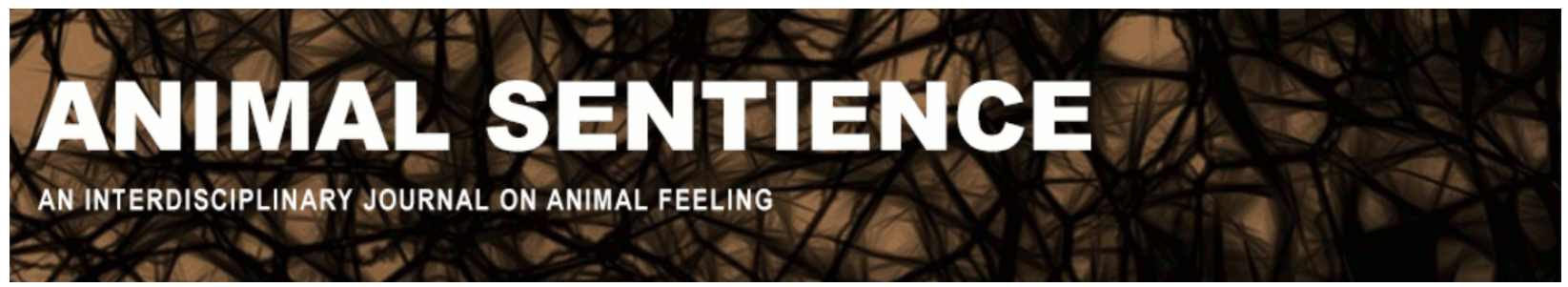

Diggles, B. K. (2016) Fish pain: Would it change current best practice in the real world?. Animal Sentience 3(35)

DOI: $10.51291 / 2377-7478.1068$

Date of submission: $2015-11-26$

Date of acceptance: 2015-12-13

(c)

This article has appeared in the journal Animal

Sentience, a peer-reviewed journal on animal

cognition and feeling. It has been made open access,

free for all, by WellBeing International and deposited

in the WBI Studies Repository. For more information,

please contact

wbisr-info@wellbeingintl.org.

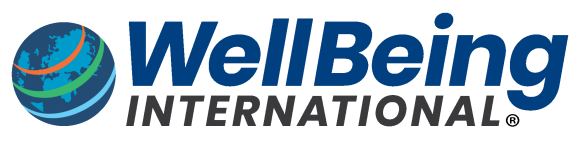

SOLUTIONS FOR PEOPLE, ANIMALS AND ENVIRONMENT 


\title{
Fish pain: Would it change current best practice in the real world?
}

\author{
Commentary on Key on Fish Pain
}

\author{
B. K. Diggles \\ DigsFish Services Pty Ltd
}

\begin{abstract}
Much of the "fish pain debate" relates to how high the bar for pain should be set. The close phylogenetic affinities of teleosts with cartilaginous fishes which appear to lack nociceptors suggests caution should be applied by those who seek to lower the bar, especially given the equivocal and conflicting nature of the experimental data currently available for teleosts. Nevertheless, even if we assume fish "feel pain," it is difficult to see how current best practice in aquaculture would change. This is because of the need to avoid stress at all stages of the rearing process to optimize health, growth performance and post-slaughter product quality. For recreational angling, while the capture process may be stressful, there are data that suggest it is not painful, and the stress can be minimised using current best practice guidelines for recreational fisheries. In commercial fisheries, however, changes to current best practices may be required for some activities if fish pain were resolved in the affirmative.
\end{abstract}

Ben Diggles ben@digsfish.com is an aquatic animal health specialist who for the last 25 years has studied various aspects relating to health, welfare and diseases of wild and captive fish, crustaceans and molluscs in both fisheries and aquaculture. Banksia Beach, QLD 4507, Australia http://www.digsfish.com/

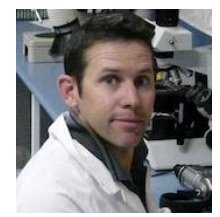

The subject of Key's target article on fish pain is controversial, so it's refreshing to read positive suggestions for progress in the field (Panksepp). In the meantime, it's obvious there is no scientific consensus that fish (or invertebrates) can "feel pain." Ignoring misunderstandings regarding fundamental differences between nociception and pain (Dinets), much of the debate is not necessarily about "yes" or "no," but "how high should the bar for fish pain be set?" Part of the problem is not only the word "feel" ( describe a human emotional experience. "Pain" may be accurate when discussing the relative experiences of humans and closely related primates, other mammals, or even birds. However, as taxa further and further away in evolutionary terms from humans are considered, it's reasonable to ask how analogous their experiences to noxious stimuli are to the human experience, and therefore how relevant phylogenetically retrospective use of the word "pain" becomes.

Most people agree that bony fishes (teleosts) are dissimilar to humans in many ways, so is it appropriate to use the word "pain" to describe processing of nociceptive stimuli in these taxa? Indeed, use of this word appears inappropriate in the case of elasmobranchs, where it appears nociceptors are absent (Snow et al. 1993, Smith \& Lewin 2009). Given the phylogenetic affinities of cartilaginous and bony fishes, I concur with Derbyshire when he states, "noxious stimulation in fish, therefore, should not be called pain because it is clearly far from the typical pain 
experience that we know. Use of the term 'pain' is mischievous; it unreasonably invites equivalence between what we would expect to feel when hooked and what a fish will feel when hooked."

Derbyshire's thesis holds true when the results of Eckroth et al. (2014) are considered. They found hooking Atlantic cod (Gadus morhua) in the "lip" with a fish hook was, aside from some temporary head shaking, equivalent to the allegedly "non-painful" control treatment (saline injection), noting "an almost complete absence of observable responses to punctate mechanical injury of the lip." This evidence appears to dismiss any suggestion of equivalence between what cod and humans "feel," at least in relation to fish hooks lodged in the lip. This was also recognized by Rose et al. (2014) who noted that hooking a fish in the lip was equivalent to the allegedly non-painful control saline injection treatments used by Sneddon (2003) for trout, but without the added injection of saline. Indeed, the results of Eckroth et al. (2014) together with the apparent lack of nociceptors in cartilaginous fishes leads to a conclusion of "no pain (in the human sense of the word) when hooked" in both cartilaginous and bony fishes (Rose).

Many will take offense at these logical conclusions from the above studies, but as Stevens points out, the bottom line for all of this should be: how does it relate to the actual welfare of fish? It appears for many fish pain advocates the concept of fish welfare is intrinsically linked to whether they feel pain (Balcombe, Brown, Goncalves-de-Freitas, Jones, Wadiwel), which may be why there is such a concerted effort by some researchers to try to prove they do (Sneddon \& Leach). However, fish pain skeptics (e.g., Rose et al. 2014, Rose) state that whether fish feel pain should not diminish concerns for their welfare. Instead, they consider that fish welfare decisions should be based on clearly validated indices such as health, reproduction, stress responses, growth, and disease resistance (Rose et al. 2014) - all of which in the real world are superior functional or nature-based welfare metrics compared to the highly speculative, non-validated feelings-based approaches (Arlinghaus et al. 2009, Diggles et al. 2011).

I often wonder whether it would change current best practice in aquaculture or fisheries if the bar were lowered to assume a "yes" answer to fish pain. In the case of aquaculture, I think not. This is because the negative relationship between stress, fish performance (Snieszko 1974, Schreck et al. 2001) and post-slaughter product quality indices (Poli et al. 2005) suggests a fundamental requirement to minimise stress in order to optimize growth and prevent disease throughout the entire production cycle (Hastein et al. 2005, Ashley 2007) including slaughter (Southgate \& Wall 2001). Although it is impossible to find one welfare indicator to cover all species and rearing systems (Mueller-Graf et al. 2012), best practice in aquaculture is congruent with good fish welfare outcomes regardless of pain, because conventional functional indicators of stress are more sensitive and can detect husbandry-related issues well before tissues are damaged (and presumably, nociceptors are activated).

The case with fisheries is less clear. For recreational fishing, while the angling process is known to be stressful in most circumstances (Arlinghaus et al. 2009), there is data to suggest it is not painful (Eckroth et al. 2014). Together with the fact that fishing hooks are not tipped with venom or acid, the findings of Eckroth et al. (2014) make the advice of Mettam et al. (2011), 
who suggest removal of fish hooks should require use of local anaesthetics, seem highly questionable. These data also suggest that calls by some (Wadiwel) to ban catch and release angling and "end recreational fishing" based on fish pain are not scientifically defensible, especially given the high potential for retrograde fish welfare and fisheries management outcomes from such approaches (Arlinghaus et al. 2007, 2009, Diggles et al. 2011, Rose et al. 2014). Indeed, a large amount of work has already been done to identify best practice methods for recreational angling to minimise stress (Recfish Australia 2001, EIFAC 2008, FAO 2012), up to and including slaughter (Diggles 2015). It appears unlikely that any of these recommendations would change if fish pain were resolved in the affirmative.

In commercial fisheries, however, there may be intractable issues around the inability to control injury and slaughter humanely while taking large numbers of fish in nets and trawls. This is one area where significant changes to current best practices may occur if fish pain were resolved in the affirmative. Even so, use of emotive anti-fishing statements like "total collapse of the fishing industry by the year 2048" by Jones are not helpful, or indeed scientifically accurate (Branch 2013), so they should be avoided, as they only encourage further mischief and controversy that may increase citations, but they do little else of practical value (Hilborn 2006).

Wadiwel states, "the very least we can do is to adopt basic welfare precautions to mitigate the potential impact if fish do suffer, with attention to the means used to capture, handle and slaughter them." Clearly, with the various best practice resources for fisheries and aquaculture, this has already been done in the majority of instances. Not that I think this will halt the debate, especially given that the animal rights viewpoint (Wadiwel) is fundamentally opposed to animal use (Arlinghaus et al. 2007). Perhaps the answer is robot fish (Chella). But then again, perhaps not. Sure, they could be programmed to be challenging to catch, but I'm pretty sure they won't be any good to eat.

\section{References}

Arlinghaus, R., Cooke, S. J., Schwab, A. \& Cowx, I. G. (2007). Fish welfare: a challenge of the feelings-based approach, with implications for recreational fishing. Fish Fish 8, 57-71.

Arlinghaus, R., Schwab, A., Cooke, S.J. \& Cowx, I.G. (2009). Contrasting pragmatic and sufferingcentred approaches to fish welfare in recreational angling. J Fish Biol 75, 2448-2463.

Ashley, P.J. (2007). Fish welfare: current issues in aquaculture. Appl Anim Behav Sci 104, 199235.

Balcombe, J. (2016). Cognitive evidence of fish sentience. Animal Sentience 2016.008

Brown, C. (2016). Comparative evolutionary approach to pain perception in fishes. Animal Sentience 2016.011 
Branch, T.A. (2013). Citation patterns of a controversial and high-impact paper: Worm et al. (2006) "Impacts of biodiversity loss on ocean ecosystem services."PLoS ONE 8(2), e56723. doi: 10.1371/journal.pone.0056723

Chella, A. (2016). Robot fish do not need sentience. Animal Sentience 2016.012

Dinets, V. (2016). No cortex, no cry. Animal Sentience 2016.013

Derbyshire, S.W.G. (2016). Fish lack the brains and psychology for pain. Animal Sentience 2016.025

Diggles, B.K. (2015). Development of resources to promote best practice in the humane dispatch of finfish caught by recreational fishers. Fish Man Ecol. doi: 10.1111/fme.12127

Diggles, B.K., Cooke, S.J., Rose, J.D. \& Sawynok, W. (2011). Ecology and welfare of aquatic animals in wild capture fisheries. Rev Fish Biol Fish 21, 739-765.

Eckroth, J.R., Aas-Hansen, O., Sneddon, L.U., Bicha, H. \& Døving, K.B. (2014). Physiological and behavioural responses to noxious stimuli in the Atlantic Cod (Gadus morhua). PLoS ONE 9(6), e100150. doi:10.1371/journal.pone.0100150

European Inland Fisheries Advisory Commission. (2008). EIFAC code of practice for recreational fisheries. EIFAC Occasional Paper, No. 42. Rome, FAO. 45p.

FAO. (2012). Recreational Fisheries. Technical Guidelines for Responsible Fisheries. No. 13. Rome, FAO. 176p.

Goncalves-de-Freitas, E. (2016). Pain and fish welfare. Animal Sentience 2016.029

Hastein, T., Scarfe, A.D. \& Lund, V.L. (2005). Science-based assessment of welfare: aquatic animals. Rev Sci Tech Int Office Epiz 24, 529-547.

Hilborn, R. (2006). Faith-based fisheries. Fisheries 31, 554-555.

Jones, R.C. (2016). Fish sentience and the precautionary principle. Animal Sentience 2016.016

Key, B. (2016). Why fish do not feel pain. Animal Sentience 2016.003

Mettam, J.J., Oulton, L.J., McCrohan, C.R. \& Sneddon, L.U. (2011). The efficacy of three types of analgesic drugs in reducing pain in the rainbow trout, Oncorhnchus mykiss. Appl Anim Behav Sci 133, 265-274. 
Muller-Graf, C., Berthe, F., Grudnik, T., Peeler, E. \& Afonso, A. (2012). Risk assessment in fish welfare, applications and limitations. Fish Physiol Biochem 38, 231-241. doi:

10.1007/s10695-011-9520-1

Panksepp, J. (2016). Brain processes for "good" and "bad" feelings: How far back in evolution? Animal Sentience 2016.031

Poli, B.M., Parisi, G., Scappini, F. \& Zampacavallo, G. (2005). Fish welfare and quality as affected by presaughter and slaughter management. Aquacult Int 13, 29-49.

Recfish Australia. (2008). A national code of practice for recreational and sport fishing. http://recfishaustralia.org.au/wp-content/uploads/2014/11/Recfish-Australia-NCOPbrochure.pdf

Rose, J.D., Arlinghaus, R., Cooke, S.J., Diggles, B.K., Sawynok, W., Stevens, E.D. \& Wynne, C.D.L. (2015). Can fish really feel pain? Fish Fish 15, 97-133.

Rose, J.D. (2016). Pain in fish: weighing the evidence. Animal Sentience 2016.032

Schreck, C.B., Contreras-Sanchez, W., \& Fitzpatrick, M.S. (2001). Effects of stress on fish reproduction, gamete quality, and progeny. Aquacult 197, 3-24

Smith, E.S. \& Lewin, G.R. (2009). Nociceptors: a phylogenetic review. J Comp Physiol A 195, 1089-1106.

Sneddon, L.U. (2003). The evidence for pain in fish. Use of morphine as an anaesthetic. Appl Anim Behav Sci 83, 153-162.

Sneddon, L.U. \& Leach, M. (2016). Anthropomorphic denial of fish pain. Animal Sentience 2016.035

Snieszko, S.F. (1974). The effects of environmental stress on outbreaks of infectious diseases of fishes. J Fish Biol 6, 197-208.

Snow, P.J., Plenderleith, M.B. \& Wright, L.L. (1993). Quantitative study of primary sensory neurone populations of three species of elasmobranch fish. J Comp Neurol 334, 97- 103.

Stevens, E. D. (2016). Why is fish "feeling" pain controversial? Animal Sentience 2016.036

Southgate, P. \& Wall, T. (2001). Welfare of farmed fish at slaughter. In Practice 23, 277-284.

Wadiwel, D. (2016). Fish and pain: the politics of doubt. Animal Sentience 2016.038 